\title{
O ideal clássico de língua em diálogos do século XVI: memória e representação do português
}

"E vós, Tágides minhas, pois criado Tendes em mi um novo engenho ardente, Se sempre em verso humilde celebrado

Foi de mi vosso rio alegremente, Dai-me agora um som alto e sublimado, Um estilo grandíloco e corrente, Por que de vossas águas Febo ordene Que não tenham inveja às de Hipocrene."

(Camões)

\section{Thiago Zilio-Passerini ${ }^{1}$}

\section{Considerações Iniciais}

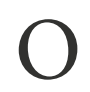

s versos da epígrafe, extraídos d'Os Lusíadas, mostram a evocação do poeta às Tágides, ninfas habitantes do rio Tejo, para que o auxiliem na missão de cantar os feitos do povo português, o grande protagonista na conquista territorial

\footnotetext{
Doutorando em Língua Portuguesa PUC-SP, mestre e Especialista em Língua Portuguesa pela PUC-SP. Membro do Grupo de Pesquisa de História das Ideias Linguísticas (Brasil e Portugal) e Identidade Nacional da PUC-SP, coordenado pela Prof $\mathrm{Dr}^{\mathrm{a}}$ Leonor Lopes Fávero. Ex-bolsista do governo grego, no Institute for Balkan Studies, em Tessalônica, e na University of Crete, em Retimno. Contato: thizilio@yahoo.com.
} 
do Novo Mundo. Na epopeia, elas figuram como musas, as responsáveis por inspirar o engenho humano em todas as suas formas e manifestações.

O contexto de produção da obra liga-se ao Classicismo, movimento artístico do século XVI baseado nos ideais do Renascimento. Esse período foi de considerável mudança do espírito europeu, até então ligado ao teocentrismo vicejante durante a Idade Média. Posto o ser humano no centro do universo, mudam-se as perspectivas e, por conseguinte, as formas de lidar com o mundo. Na ocasião, ressurge o elemento greco-latino, incontestável fonte de inspiração para os artistas e pensadores da época.

Neste capítulo, temos o objetivo de demonstrar de que maneira se apresenta o ideal clássico de língua em textos escritos no século XVI, a partir do conceito de representação de Chartier (1991 [1989]). Para tanto, também mobilizamos o conceito de memória postulado por Le Goff (2016 [1990]) e Ricoeur (2018 [2007]), a fim de mensurar em que medida ele se relaciona à representação.

O corpus analisado compõe-se de dois diálogos que tratam do português, escritos em diferentes momentos, por diferentes autores. O primeiro é o Diálogo em louvor à nossa linguagem, de João de Barros, publicado em 1540; o segundo é o Diálogo em defesa da língua portuguesa, de autoria de Pero Magalhães de Gândavo, que veio a lume em 1574. A análise dos documentos baseou-se nos princípios da História das Ideias Linguísticas postulados por Auroux (2014 [1992]), considerando a definição fenomenológica do objeto, a neutralidade epistemológica e o historicismo moderado.

\section{O poder da Memória: representação e identidade}

No título deste trabalho, aludimos à Memória, entidade mitológica identificada entre os gregos como Mnemósine. Não por acaso, a epígrafe escolhida menciona as musas, filhas dessa divindade, segundo a mitologia grega. De acordo com Brandão (2015 [1986], p.213), a palavra musa origina-se do verbo $\mu a v \theta$ áveเv, cujo significado em grego antigo ${ }^{2}$ era "aprender". O autor ainda destaca que as palavras música - algo pertencente às musas - e museu - o templo, a morada dessas divindades - também fazem parte da mesma família etimológica.

Acerca da Memória, Pugliesi (2005, p.259) considera que, sob seus domínios, estavam "os princípios da educação do homem grego. A verdade decorre do recordar-se, e a aprendizagem, pelo menos até o século III a.C., está estreitamente

2 Fazemos a distinção do grego antigo, pois, em grego moderno, o verbo é $\mu \alpha \theta \alpha i ́ v \omega$ (mathéno) e conserva o mesmo significado. 
O ideal clássico de língua em diálogos do século XVI:

vinculada a essa deusa. Assim, por exemplo, a maiêutica socrática presta-lhe vigoroso reconhecimento". Diante disso, fica mais evidente a relação entre as suas filhas musas e o étimo manthánein.

Hesíodo (2001), em sua Teogonia, foi o primeiro a ocupar-se da relação entre essas divindades. Sobre elas, o sábio grego assim se pronuncia:

Então as deusas, do início ao fim de seus cantares, louvam a Zeus,

Pai dos deuses e dos homens

O melhor dos deuses e o maior em força.

As Musas Olímpicas, filhas de Zeus, o que porta a égide

Louvam a raça dos homens e dos poderosos Gigantes

E deleitam o espírito de Zeus no Olimpo.

Mnemósine, que senhoreia as colinas de Eleutera,

Unindo-se ao pai, filho de Cronos, gerou-as na Piéria

Para esquecimento das desventuras e repouso das aflições.

Por nove noites, uniu-se a ela o Zeus prudente,

Distante dos imortais, subindo -lhe ao sagrado leito.

Quando o tempo se completou, e as estações voltearam

Ao fim dos meses e ao passar de muitos dias

Pouco abaixo do altíssimo cume do Olimpo níveo,

Deu à luz nove filhas uníssonas que, do fundo do seu peito,

Tão somente lhes importa a canção e têm despreocupado ânimo ${ }^{3}$.

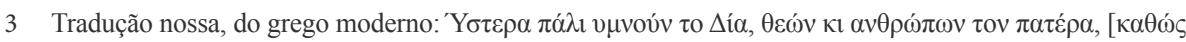

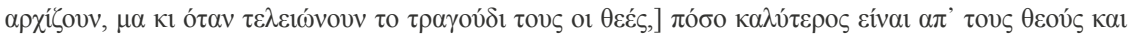

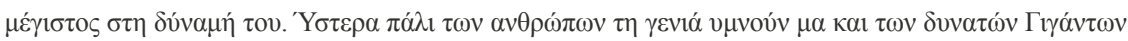

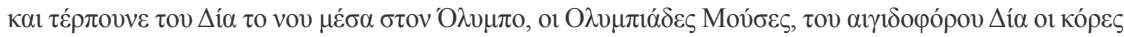

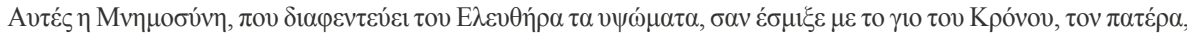

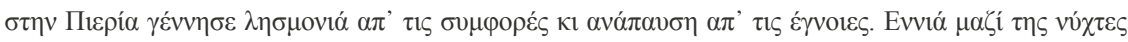

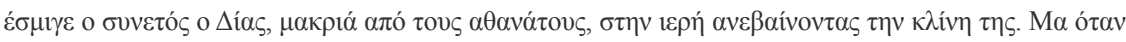

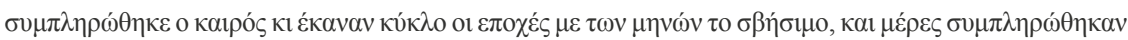

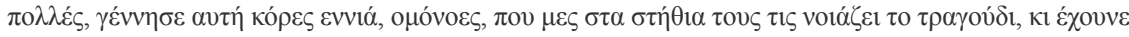

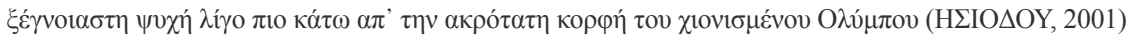


Torrano (1995, p.11) assinala a importância do aedo em uma sociedade anterior à adoção do alfabeto. Nesse contexto, o canto assume a capacidade de presentificar os feitos de outrora, e o poeta tem o poder de "ultrapassar e superar todos os bloqueios e distâncias espaciais e temporais". Para tanto, as musas, personificação da palavra cantada, são geradas "[...]da Memória (num sentido psicológico, inclusive) e do mais alto exercício do Poder (num sentido político, inclusive) ".

Se, para os gregos antigos, a figura de Mnemósine era indispensável à manutenção da identidade do povo, para o homem contemporâneo, ela continua sendo "um elemento essencial do que se costuma chamar identidade, individual ou coletiva" (LE GOFF, 2016 [1990], p. 435, grifo do autor). Nesse sentido, ressalta-se o aspecto coletivo da memória, ou seja, ela não se reduz às recordações individuais. Por essa razão,

A evolução das sociedades, na segunda metade do século XX, elucida a importância do papel que a memória coletiva desempenha. Exorbitando a história como ciência e como culto público, a mesmo tempo a montante, enquanto reservatório (móvel) da história, rico em arquivos e documentos/monumentos, e aval, eco sonoro (e vivo) do trabalho histórico, a memória coletiva faz parte das grandes questões das sociedades desenvolvidas e das sociedades em vias de desenvolvimento, das classes dominantes e das classes dominadas, lutando, todas, pelo poder ou pela vida, pela sobrevivência e pela promoção (LE GOFF, 2016 [1990], p.435).

Da fala do autor, destacamos a questão das classes envolvidas no processo de construção da memória, quase sempre vinculada à vontade das classes dominantes. Assim, ela pode ser manipulada de acordo com os interesses dos que, em determinado momento, se encontram no poder. Sobre essa questão, Ricoeur (2018 [2007]) adverte que a manipulação pode ocorrer por influência da ideologia imperante.

Segundo Chartier (1991 [1989]), as questões identitárias mantêm-se intimamente ligadas à representação. Para ele, a própria noção do real depende dos grupos que fazem parte de determinada sociedade. Mais do que isso, a existência desses grupos depende da representação que fazem de si para si e para os outros. Nas palavras do autor,

Uma dupla via abre-se assim: uma que pensa a construção das identidades sociais como resultando sempre de uma relação de força entre as representações impostas pelos que detêm o poder de classificar e de nomear e a definição, de aceitação ou de resistência, que cada comunidade produz de si mesma (21); outra que considera o recorte social 
O ideal clássico de língua em diálogos do século XVI:

objetivado como a tradução do crédito conferido à representação que cada grupo dá de si mesmo, logo a sua capacidade de fazer reconhecer sua existência a partir de uma demonstração de unidade (22) [...] (CHARTIER, 1991 [1989], p. 183).

Desse modo, fica clara a relação entre a representação e a memória. Inicialmente, pelo fato de elas serem essenciais à identidade de determinado grupo, pois constroem a sua imagem dentro e fora da comunidade - e aqui ressaltamos o papel didático de ambas, posto que também ensinam as gerações vindouras. Posteriormente, pelo fato de a própria memória ser responsável, em grande medida, pela representação de inúmeros valores, crenças e dogmas de determinado grupo.

Ao mesmo tempo, é possível pensar que a representação precede à memória, lançando as sementes simbólicas daquilo que fará parte do pensamento coletivo de uma sociedade. De todo modo, tanto a memória quanto a representação são materialidades visíveis nos textos que compõem o corpus deste capítulo, como se verá oportunamente.

\section{O Renascimento e o Portugal quinhentista: clima de opinião}

Conforme assinala Sichel (1963 [1957], p.7), o Renascimento foi "um movimento, uma revivificação das capacidades do homem, um novo despertar da consciência de si próprio e do universo". Nessa condição, ainda segundo a autora, ele teria perdurado por cerca de dois séculos, em pleno vigor entre 1400 e 1600 na Europa ocidental. Antes de ser um "ritual estético", era, na verdade, uma "disposição de espírito, uma visão nova, uma fonte de pensamentos e obras".

O sopro de renovação que animou o espírito da época possibilitou uma série de transformações nas mais diversas áreas do conhecimento humano, permeando não somente a ciência, mas também as artes. No cerne de tais mudanças, verifica-se uma postura de verdadeiro repúdio àquilo que Burke (2010 [1999]) chamou de "tradições recentes". Elas seriam, de acordo com o autor, os ideais medievais. Assim, o "moderno" surgiu como resposta àquilo que se queria/deveria combater.

Para tanto, promoveu-se um retorno à Antiguidade Clássica, e a influência greco-latina se fez presente nos mais diversos campos do saber e da expressão renascentistas. No entanto, devemos ponderar que o retorno a esse período da história não se deu de modo fortuito. O início da Idade Moderna está atrelado justamente à tomada de Constantinopla pelos turcos, em 1453. Com isso, o co- 
nhecimento helênico se dispersou, e um considerável volume de manuscritos e esculturas, fruto de saques, chegou à porção oeste do território europeu (SICHEL, 1963 [1957], p.8). Assim, a atmosfera de "descoberta" desse verdadeiro tesouro do conhecimento humano fez com que a cultura greco-romana se tornasse um modelo a ser seguido.

A onda de transformação que varreu as paragens europeias causou impactos de diferentes intensidades no Velho Mundo. $\mathrm{O}$ auge se deu, indubitavelmente, na Itália, considerada o berço do movimento. No entanto, também destacamos a pujança renascentista na Alemanha, na França e na Inglaterra. Já na Península Ibérica, o Renascimento manifestou-se mais discretamente, se comparado aos exemplos anteriores.

No século XVI, Portugal vivia o apogeu das conquistas ultramarinas, iniciadas na centúria anterior. A chegada ao "Novo Mundo" provocou inúmeras alterações políticas, sociais e culturais, e o pequeno e incipiente território de antanho tornou-se um império, erigido sobre as ondas e para além delas. Durante pelo menos trinta anos, o reino foi símbolo de uma prosperidade que não mais se repetiu ao longo da história portuguesa (SCOTT, 2018, p.244).

Com relação à colonização, o espírito cruzadista presente nos primórdios das grandes navegações converteu-se em missionário. Por isso, a preocupação com o envio de religiosos para a catequização dos gentios intensificou-se desde o início do Quinhentos. Essa mudança de postura por parte do governo foi crucial para as políticas educacionais adotadas no reino.

Do ponto de vista cultural, especialmente durante o reinado de D. João III, houve financiamento régio de estudos a serem realizados no exterior. Segundo Garcia (1983, p. 130), inúmeras bolsas de estudo foram concedidas para que alunos frequentassem escolas superiores na França e na Espanha. Além desses dois destinos, o afluxo de portugueses à Itália era considerável, tanto por questões culturais quanto religiosas. Todo esse intercâmbio propiciou o desenvolvimento do espírito renascentista no solo lusitano.

As mudanças no âmbito educacional notabilizaram-se tanto na formação básica quanto na superior. Fundaram-se inúmeros colégios, e os já existentes passaram por profundas reformas. Assim, surgiram, por exemplo, os colégios maiores, destinados à formação universitária, e os colégios menores, destinados à preparação dos alunos para o ingresso nas universidades. No período, merece destaque a fundação da Universidade de Coimbra, em 1537, em decorrência do encerramento das atividades da Universidade de Lisboa.

Com o surgimento da tipografia, houve aumento na produção de livros, o que também incentivou não só a produção intelectual, mas também a instrução, ainda que das classes mais abastadas. Conforme assinala Marques (2003, p. 183), cerca da metade da produção era voltada a temas religiosos, e apenas 
O ideal clássico de língua em diálogos do século XVI:

memória e representação do português

um décimo era dedicado à ciência efetivamente. Os outros títulos variavam entre poucas obras classicistas e muitas traduções, devido à consolidação do uso do português.

Apesar do desenvolvimento de uma cultura antropocêntrica, ela nunca atingiu seu esplendor. De acordo com Scott (2018, p. 251), a presença da autoridade religiosa foi decisiva para os destinos seguidos por Portugal e responsável por refrear o avanço do reino. Do ponto de vista econômico, pelo fato de "colocar sérios obstáculos ao desenvolvimento do capitalismo, ao privar Portugal de gente com recursos financeiros significativos e de contatos comerciais relevantes nas mais importantes praças de comércio". Do ponto de vista do conhecimento, porque a "intolerância religiosa obrigou o país também a abrir mão de um capital imaterial relevante aos sabores científico, técnico e médico".

Os efeitos dos problemas originados da política administrativa adotada passaram a ser sentidos na segunda metade do século XVI e atingiram o ápice em 1578. Na ocasião, ocorreu a lendária batalha de Alcácer-Quibir, que resultou no desaparecimento de D. Sebastião. A morte do monarca trouxe a Portugal inúmeros problemas, decisivos para a crise sucessória que levou o reino a ser anexado à Espanha dois anos mais tarde, em 1580.

\section{O retorno do gênero diálogo: circulação de saberes à moda grega}

A atmosfera de retorno ao passado clássico influenciou diretamente o ressurgimento de gêneros que gozavam de grande prestígio entre os gregos e os romanos. Em Portugal, muitos foram retomados após a volta de Sá de Miranda da Itália, entre eles a ode, a elegia, a égloga e a comédia clássica (MOISÉS, 1999 [1960], p. 50). A própria publicação d'Os Lusíadas é prova do reaparecimento da epopeia, imortalizada por Homero e Virgílio.

Com relação à Filosofia, o Renascimento possibilitou, sobretudo a partir do século XV, o reaparecimento de Platão, cujas ideias tinham sido sumariamente abandonadas durante a Idade Média, devido à valorização do pensamento de Aristóteles, fundamental para a construção das bases da escolástica de São Tomás de Aquino (D'ONOFRIO, 2007, p.222). Ao mesmo tempo, o gênero diálogo, largamente utilizado pelo mais conhecido discípulo de Sócrates, também ressurgiu.

Segundo Rossetti (2015 [2011]), os diálogos passaram a ser escritos no século IV a.C., especificamente nas primeiras décadas após a morte de Sócrates. Para o autor, embora fossem uma novidade para época, esses textos eram, na verdade, uma representação do modo como o filósofo grego conduzia o seu 
pensamento, interrogando o seu interlocutor acerca de determinado assunto. Sobre a questão, Santos (2012 [2008], p. 11) considera:

O primeiro [problema na questão dos diálogos] é a metodologia seguida por Sócrates em suas refutações - o élenchos - e da concepção de saber nela implícita. Embora encaremos "Sócrates" como a personagem dos diálogos sobre quem recai a tarefa de conduzir as investigações, cremos ser possível atribuir à metodologia de 'pergunta e resposta', a que submete seus interlocutores, consistência bastante para a avaliarmos como uma concepção de saber definida, subjacente aos diálogos[...]

Desse modo, não se trata de um gênero instituído a partir da circulação dos textos dialogais. Antes disso, a prática já era comum e largamente usada por Sócrates, embora tivesse sido registrada postumamente por seus discípulos. Nesse sentido, ela se liga indissociavelmente à dialética, entendida inicialmente como a arte do diálogo e posteriormente como a arte de demonstrar uma tese por meio do diálogo, levantando questões concernentes ao tema discutido (KONDER, 2007 [1981]).

As causas que justificam o surgimento dos diálogos e o seu florescimento depois da morte de Sócrates são diversas. No entanto, três delas merecem destaque, ainda de acordo com Rossetti (2015, pp.44-45): o processo de padronização da forma como o filósofo orientava suas conversas, constituindo o seu $\lambda$ ó $\pi \rho о \tau \rho \varepsilon \pi \tau$ «ó $\varsigma^{4}$; a tentativa de seus discípulos manterem viva a lembrança de seu mestre, dissipando a carga negativa adquirida depois da cicuta; e a grande aceitação do público, logo após as primeiras tentativas de recriar a metodologia socrática.

Além da motivação relacionada à figura de Sócrates, outras razões levaram Platão a escolher o diálogo como forma principal de transmitir seu conhecimento, em detrimento dos costumeiros tratados de filosofia. Na visão de Santos (2012 [2008], pp.36-38), elas teriam relação com a própria concepção platônica de "conhecimento, de aprendizagem e de educação". Assim, sob a ótica de Platão, os textos dialogais impediam o plágio, posto que as ideias eram atribuídas a personagens claramente identificadas. Já o texto corrido, sem a possibilidade

4 Leia-se lógos protreptikós. A tradução da expressão seria exatamente “diálogo motivacional ou encorajador". Compreendida a forma como Sócrates conduzia a sua interlocução, podemos considerar o seu discurso como exortativo, que visa a persuadir o interlocutor por meio das questões ou até mesmo dissuadi-lo de suas convicções, postas à prova por meio das perguntas. 
O ideal clássico de língua em diálogos do século XVI:

memória e representação do português

de questionamentos diretos, favoreceria uma postura acrítica por parte do leitor acerca do conteúdo lido.

Outro ponto que merece destaque é a categorização dos diálogos, de acordo com a natureza de cada texto. Grosso modo, eles se dividem em três grupos: o dos diálogos elênticos; o dos que se apresentam mais como uma investigação do que como debate propriamente dito; e o da trilogia dramática de Teeteto. O primeiro grupo se caracteriza pela utilização do método pergunta-resposta visando à discussão da virtude. $\mathrm{O}$ segundo grupo volta-se mais à investigação de determinado tema do que ao próprio debate e tem ligação com a teoria das formas. O terceiro grupo centra-se na figura de Teeteto, que dialoga com diferentes interlocutores sobre a natureza do saber (SANTOS, 2012 [2008]).

Como podemos perceber, o gênero apresenta uma série de particularidades e não deve ser concebido como uma simples "conversa" acerca de determinado assunto. Mais do que isso, trata-se de um complexo método de debate que, para Sócrates, consistia no modo de refutar o seu ouvinte, convencendo-o da impossibilidade de dominar plenamente qualquer questão. Platão se vale do mesmo recurso para conduzir suas investigações filosóficas, bem como da figura de seu mestre para protagonizar muitos de seus textos.

No contexto renascentista, o gênero foi amplamente utilizado e se tornou a forma quase absoluta de divulgação dos saberes. A razão dessa escolha certamente vai além da "redescoberta" de Platão, e vários fatores, por vezes antagônicos, podem ter motivado o seu florescimento na Idade Moderna. De acordo com Konder (2007 [1981], p. 14), houve um ressurgimento da dialética, permitindo que ela alcançasse posições mantidas inclusive nos séculos posteriores ao Renascimento, fator que talvez tivesse impulsionado a escrita de textos dialogais.

Já para Adami (2017), foi justamente a postura contrária à dialética que teria motivado o surgimento dos diálogos, como forma de valorizar a Retórica frente à Filosofia. Segundo a autora, muitos pensadores humanistas rebelaram-se contra a dialética, justamente por ela representar, durante a Idade Média, “[...] uma subserviência do pensamento (ou da ciência) às categorias escolásticas. O método de perguntas e respostas nos moldes da lógica de Aristóteles havia se tornado o método universal por excelência para leitura e interpretação de textos, bem como na demonstração dos autos de fé".

De todo modo, quer tenha sido pelo ressurgimento da dialética, quer tenha sido pela luta contra ela, os diálogos se multiplicaram em diversas partes da Europa renascentista. De acordo com Hue (2007, p. 18), eles se tornaram “ [...] o gênero que se prestava à discussão de temas da atualidade, contemporâneos, e à apresentação de todo tipo de conteúdo". Por essa razão, em Portugal, publicaram-se mais de quarenta textos dessa natureza, de temática igualmente variada. Dois se ocupavam de questões linguísticas e são o foco de nosso estudo. 


\section{As ideias linguísticas do século XVI: breves considerações}

A atmosfera de renovação renascentista foi muito significativa para o desenvolvimento dos estudos linguísticos da Idade Moderna. A princípio, destacamos a atenção dada às línguas antigas, sobretudo ao grego, ao hebraico e ao latim. Esse interesse se explica, em grande medida, pela ação de retorno ao passado greco-latino, em voga na ocasião. Além disso, o processo de descrição das chamadas "línguas do mundo" atingiu proporções consideráveis.

Conforme assinalam Colombat, Fournier e Puech (2017 [2010]), no século XVI, o número de línguas descritas chegou a 33 e aumentou substancialmente nos séculos ulteriores. Esses estudos foram motivados principalmente pela expansão territorial protagonizada por alguns países da Europa, que propiciou o contato com as línguas dos povos colonizados e, consequentemente, a sua instrumentalização. No Brasil, por exemplo, José de Anchieta escreveu a Arte de Gramática da língua mais usada na costa do Brasil, publicada em 1595.

Desse modo, o Cinquecento tornou-se um dos períodos de maior produtividade da gramatização $0^{5}$ das línguas "exóticas" e europeias. No contexto europeu, outros fatores impulsionaram a escrita de gramáticas e dicionários, além da expansão colonial. Como já dissemos, a invenção da imprensa promoveu um aumento considerável no número de publicações e, por essa razão, havia a necessidade de instrumentalizar as línguas. Além disso, elas passaram a ser oficializadas nos reinos - embora ainda convivessem com o latim - e atingiram sua "maturidade" justamente no século XVI. Em suma,

Não há, entretanto, nada de comparável, quantitativa ou qualitativamente ao processo que se dá no final do século XV a partir das línguas que vão daí para frente dominar a história da Europa (italiano, espanhol, francês, português, alemão, inglês) mas também do húngaro (1539), do polonês (1568) e do velho eslavo (1596), processo que, fortificando-se, atingirá, no início do século XIX, a maior parte das línguas escandinavas, eslavas, como também as fino-ugrianas, as quais, assim como o basco, não pertencem à família indo-européia [...] (AUROUX, 2014 [1992], pp.37-40).

5 De acordo com Auroux (2014 [1992], p. 65, grifos do autor), "Por gramatização deve-se entender o processo que conduz a descrever e a instrumentalizar uma língua na base de duas tecnologias, que são ainda hoje os pilares de nosso saber metalinguístico: a gramática e o dicionário" 
O ideal clássico de língua em diálogos do século XVI:

O processo de descrição das línguas favoreceu substancialmente o seu estudo sob uma perspectiva mais ligada à forma. Assim, as investigações morfológicas e fonéticas ganharam destaque. De acordo com Câmara Jr. (s/d [1975, p.35), “[...] a partir do século XVI, devido ao estudo das línguas vivas modernas, o aspecto oral da linguagem foi trazido à baila e a teoria fonética, embora rudimentar, desenvolveu-se".

Outro aspecto relevante é a existência de duas vertentes muito claras de abordagem linguística, oriundas dos estudos medievais: a grammatica speculativa e a grammatica positiva. Grosso modo, a primeira se ocupava dos aspectos mais gerais - ou universais - das línguas, e a segunda, dos mais específicos. Levando em consideração o clima de opinião, a grammatica positiva distinguiuse entre os estudos da época, e "muitas gramáticas do Renascimento, seja de línguas europeias ou de línguas mais exóticas, foram escritas com a intenção de demonstrar a 'regularidade' inerente à língua examinada" (WEEDWOOD (2006 [2002], p.72).

No entanto, a análise da regularidade não tinha como base as línguas por si mesmas. Os estudos empreendidos basearam-se naquilo que Colombat, Fouriner e Puech (2017 [2010], p. 159) chamaram de "tradição greco-latina". Partindo desse modelo, produziram-se as gramáticas e, conforme destaca Weedwood (2006 [2002]., pp.72-73), acentuou-se a preocupação em demonstrar as relações entre os vernáculos e o latim, "de modo que as gramáticas mais tardias dos vernáculos são em geral mais artificialmente constrangidas pelo modelo latino do que as anteriores".

Em Portugal, o processo de gramatização teve início em 1536, com a publicação da Grammatica da lingoagem portuguesa, de Fernão de Oliveira. Quatro anos, mais tarde, João de Barros publicou a Grammatica da lingua portuguesa, acrescida do Dialogo em louvor da nossa linguagem. Posteriormente, surgem as Regras que Ensinam a Maneira de Escrever a Ortografia Portuguesa com um Diálogo que Adiante se Segue em Defensão da Mesma Língua, de Pero Magalhães de Gândavo, , publicadas em 1574, e a Ortographia da Lingoa Portuguesa, de Duarte Nunes de Leão, lançada em 1576.

Segundo assinala Spina (2011 [2008], p.287), todas elas são resultado do "desejo de disciplinar e aprimorar a língua portuguesa, numa tentativa de afeiçoá-la à mãe latina”. A afirmação do autor é de grande valia, pois contempla justamente o ideal de língua observado nos dois diálogos aqui analisados. Desse modo, a relação de "conformidade" entre o português e o latim passou a ter destaque, sobretudo depois da publicação da gramática de João de Barros.

O "desejo de disciplinar e aprimorar" o português de que nos fala Spina é, na verdade, uma resposta ao momento vivido por Portugal. Nesse sentido, evidencia-se a necessidade de se dispor de uma língua padronizada, a fim 
de atender tanto à política educacional interna de reforma do ensino quanto à política externa de promoção do idioma nas novas terras. Prova disso é a multiplicação das cartinhas para aprender a ler, cujo objetivo era "[...]além do ensino dos 'meninos portugueses', o ensino também da língua portuguesa a estrangeiros" (BUESCU, 1978, p.18).

Além disso, merece destaque a intensificação do uso do vernáculo, que teve início no reinado de D. Dinis, quando a documentação oficial passou a ser escrita prioritariamente em "linguagem", e não mais em latim (Cf. FARACO, 2016). Essa mudança demandava cada vez mais a instrumentalização da língua e também teria motivado os estudiosos da época a se debruçarem sobre a questão, como atestam as publicações das regras ortográficas de Gândavo e de Leão, por exemplo.

No contexto português, a escolha do latim como língua modelar vai além do clima de opinião, permeado pelos ideais renascentistas. Para melhor entender essa afirmação, devemos considerar que Portugal, especialmente nas primeiras décadas do século XVI, vivia o ápice das conquistas ultramarinas, o que resultou em um discurso extremamente patriótico com relação à língua, como podemos observar no preâmbulo da gramática de Fernão de Oliveira (Cf. PASSERINI, 2019b). Barros e Gândavo adotam essa mesma postura em seus diálogos, embora tenham sido compostos em diferentes momentos da história do reino.

Tendo isso em mente, o lugar ocupado pelo latim na origem da língua portuguesa serve como uma forma de conceder-lhe uma "origem nobre". Se a supremacia do império era um fato inquestionável, o idioma falado pelos protagonistas desse capítulo tão significativo da história deveria ser igualmente representado de forma grandiosa e, para tanto, carecia de um "ancestral" à altura.

Em outras palavras, uma língua imperial só poderia ter-se originado de outra com a mesma característica. Diante disso, o latim, pelas relações históricas que mantém com o português, desempenhou perfeitamente a função de "progenitor". Por essa razão, hoje também se discute o apagamento do galego no momento em que se instaura o discurso fundador da língua portuguesa (Cf. MONTEAGUDO, 1999; BAGNO, 2012; FARACO, 2016, 2019; PASSERINI, 2019b).

\section{João de Barros e Pero Magalhães de Gândavo: perfil biobibliográfico}

Os autores dos textos que analisamos, apesar de serem contemporâneos e tratarem de uma mesma questão, são substancialmente distintos quanto às esferas sociais nas quais atuaram ao longo da vida, conforme destaca Hue (2007, p. 19). Sobre João de Barros, copiosas fontes registram os feitos daquele que foi 
O ideal clássico de língua em diálogos do século XVI:

um dos maiores humanistas de Portugal. Com relação a Gândavo, escassas - ou praticamente inexistentes - são as informações biográficas, embora ele também tenha sido um ilustre humanista.

João de Barros era filho ilegítimo de Lopo de Barros, um fidalgo cujo sobrenome foi herdado da aldeia Barros, localizada na região do Entre-Douro-e-Minho. Desde muito jovem, foi criado no paço real, o que lhe proporcionou sólida formação, posteriormente aprimorada graças a seu autodidatismo. Buescu (1969) chama a atenção para duas de suas características, que nos interessam sobremaneira: a de "criptogramático" e a de pedagogo. Segundo a autora, o pendor gramatical de Barros já se observa nas Décadas - obra de grande valor histórico -, quando ele faz diversas incursões para comparar "fenômenos e sistemas idênticos em línguas diferentes". Além disso, explica etimologicamente determinados nomes presentes no texto, principalmente os topônimos.

Como pedagogo, mostra-se à frente do seu tempo, elaborando um plano de ensino de português ao qual chamamos tríade linguística barrosiana (PASSERINI, 2019b). Dela fazem parte a Cartinha com os mandamentos da santa madre igreja, publicada em 1539; a Grammatica da lingua portuguesa; e o Diálogo em louvor à nossa linguagem, ambos publicados em 1540, como já mencionamos. É nessa fase que o "criptogramático" das Décadas se torna gramático efetivamente, demonstrando toda a sua erudição e o seu conhecimento acerca do português e também do latim.

Sobre Pero Magalhães de Gândavo, acredita-se que ele teria nascido em Braga, embora fosse de origem flamenga por parte de pai. Seu sobrenome atesta a ascendência, pois está relacionado a Gand, capital da província de Flandres, na Bélgica, com quem Portugal mantinha intensa atividade comercial. Passou grande parte de sua vida na província do Entre-Douro-e-Minho, onde se casou e desempenhou as funções de professor de latim em uma escola por ele mesmo aberta. Posteriormente, dedicou-se ao ofício de professor de português, além de ter sido copista na Torre do Tombo.

Este último cargo, conforme assinala Buescu (1978), foi ocupado por Gândavo após seu retorno do Brasil, onde esteve por duas vezes: uma antes de 1569 e outra por volta de 1576. A atribuição das datas é feita com base nas suas duas obras cuja temática recai sobre a nova terra e que lhe renderam o título de nosso "primeiro historiador" : o Tratado da Província do Brasil e a História da Província de Santa Cruz. Curiosamente, a primeira só veio a lume em 1826, publicada pela Real Academia de Ciências. Na qualidade de estudioso da língua, publicou, em 1574, as Regras que ensinam a maneira de escrever e a ortografia da língua portuguesa com um diálogo que adiante se segue em defensão da mesma língua.

$\mathrm{O}$ estilo e as pretensões dos autores apresentam-se de modo distinto em suas obras. João de Barros demonstra sempre o gigantismo de seus ideais, quer seja 
nas Décadas - nas quais se valeu de um vocabulário primoroso para escrever uma significativa obra histórica, na qualidade de cronista oficial -, quer seja na Gramática - o corolário de seu projeto pedagógico do ensino de língua, no qual mobiliza todo o seu conhecimento de latim para colocar o vernáculo em pé de igualdade com a "língua de origem".

Já Pero Magalhães de Gândavo tem pretensões bem mais modestas, o que não diminui sua relevância. Ao contrário de seu antecessor, os seus tratados históricos sobre o Brasil serviam mais como forma de propagandear a colônia, com o objetivo de atrair os mais pobres do reino e estimular a colonização das novas terras. No que concerne às Regras, elas eram mais simples e teriam sido elaboradas justamente para aqueles que desconheciam o latim, com o intuito de auxiliá-los na escrita adequada do português. (HUE, 2007, p.20).

\section{Memória e representação do português: o ideal clássico de língua}

Conforme já mencionamos, uma característica marcante dos diálogos é o tom patriótico, em razão da posição de destaque ocupada por Portugal no período das grandes navegações. Trata-se de um fato relevante, pois o mesmo sentimento em relação à terra estendia-se - ou deveria se estender - à língua. No entanto, ele se coaduna com um discurso apologético que, antes de mais nada, representa uma "resposta" ao castelhano, que desempenhava papel de língua de erudição na corte portuguesa.

De posse de tais informações, podemos compreender melhor as razões do "louvor" e principalmente da "defesa" do português. Nesse sentido, Buescu (1978) assinala haver uma clara diferença entre as obras de João de Barros e Pero Magalhães de Gândavo. Segundo a autora, na obra de Barros, era nítido o discurso laudatório do idioma lusitano, com o objetivo de mostrar suas virtudes; já no texto de Gândavo, era evidente "uma clara discussão de rivalidades" acerca das línguas portuguesa e castelhana. No entanto, como já mencionamos em Passerini (2019a), no diálogo de Gândavo, a defesa também se dava por meio do louvor às qualidades do idioma, embora o objetivo do texto fosse, a priori, outro.

Se tomarmos o contexto de produção das obras, separadas por um período de 34 anos, encontramos, na própria situação vivida por Portugal, a explicação para um "louvor" nas primeiras décadas do Quinhentos e uma "defesa" nas derradeiras. Como já dissemos, os primeiros decênios configuraram o apogeu das conquistas ultramarinas, o que justifica a atitude de exaltação da língua, símbolo de um povo cujos domínios se estenderam "por mares nunca dantes navegados", como sabiamente escreveu a pena camoniana. Do mesmo modo, as 
O ideal clássico de língua em diálogos do século XVI:

memória e representação do português

últimas décadas testemunhavam a franca derrocada do império que, seis anos após a publicação da "defesa", sucumbiria ao jugo do sempre inimigo castelhano.

No título deste capítulo, fazemos alusão a um ideal clássico de língua. Por isso, antes de nos lançarmos à análise propriamente dita, devemos ter em mente o significado do termo e, para tanto, recorremos a D'Onofrio (2007, p. 217), que assim o define:

A etimologia do termo "clássico" vem do latim classis, que significava uma classe social [...] a que um cidadão romano pertencia e que o distinguia da grande massa do povo [...] A este sentido sociológico está ligada a idéia de preeminência, de excelência.

Com referência às letras, o classicus scriptor era o autor que se distinguia da maioria pela correção lingüística e pela beleza das imagens poéticas. Assim, Homero, Virgílio, Horácio, Cícero eram considerados escritores clássicos, porque constituíram 'modelos' a serem seguidos e suas obras eram estudadas nas classes das instituições escolares [...]

Das palavras do autor, destacamos o fato de o adjetivo clássico relacionar-se a um modelo a ser seguido. No âmbito dos estudos linguísticos do Cinquecento, a tradição gramatical greco-latina era o paradigma que abalizava o tratamento da língua . Mais especificamente, a gramática latina de Donato, que, segundo Colombat, Fournier e Puech (2017 [2010], p. 141), “[...] antes da descoberta de Prisciano [...] aparece como o vetor para o qual se pode manter o conhecimento quanto para a pedagogia do latim [...] e o núcleo a partir do qual se constitui o modelo da descrição das línguas do mundo[...]", fenômeno iniciado ainda na Idade Média.

Diante disso, ficam claras as razões pelas quais o latim se tornou o modelo para as demais línguas românicas. Retomando o conceito de memória por nós adotado, destacamos que essa ideia sobre a língua latina se constituiu ao longo dos séculos entre os povos falantes de línguas românicas e permaneceu viva quando surgiram as primeiras gramáticas vernaculares.

De volta aos diálogos, concentremo-nos inicialmente no louvor à língua portuguesa, de João de Barros ${ }^{6}$. A discussão instaura-se entre duas personagens, denominadas Pai e Filho. Sobre elas, devemos destacar que a primeira é o

6 Para facilitar a compreensão do leitor, todos os trechos dos diálogos transcritos foram retirados da edição crítica feita por Hue (2007), que apresenta algumas modernizações, sobretudo na ortografia. Por essa razão, os números de página correspondem aos da edição de Hue, e não aos da versão original. 
próprio Barros; já o filho, Antônio, curiosamente tem o nome revelado apenas ao fim do texto. É ele quem abre o diálogo, contando sobre o início das aulas de leitura do príncipe, sob a orientação do frei João Soares.

A partir daí, inicia-se uma longa reflexão baseada em um questionamento que circulava nos meios intelectuais da época: qual teria sido a primeira "linguagem" do mundo. O pai toma a palavra e faz um longo excurso, que perpassa questões históricas e religiosas e busca, nestas últimas, uma explicação mais convincente. Isso demonstra a força da religiosidade em Portugal, apesar do clima de opinião renascentista. Quase ao fim de sua fala, ele afirma que o mais acertado seria se ocupar de três línguas que, tal como o português, precediam a todas as outras naquele momento e cujo vocabulário fora tomado sobretudo da língua latina "que foi a derradeira que teve monarquia, cujos filhos nós somos" (BARROS, 2007 [1540], p. 46).

A afirmação é relevante principalmente se levarmos em conta o contexto de circulação do texto de Barros. Como já mencionamos, o diálogo surge quatro anos depois da publicação da obra de Fernão de Oliveira, que marca o início da gramatização da língua portuguesa. Do mesmo modo, surge o seu discurso fundador e, consequentemente, a construção da sua memória, a ser perpetuada dentro e fora de Portugal.

Para tanto, cabe aos autores a escolha de uma forma de representar o português. Como vimos em Chartier (1991 [1989]), a questão da identidade liga-se inextricavelmente à representação. Nesse sentido, a fala do pai trata de caracterizar o português e as demais línguas românicas como "filhos" do latim. Conforme constatamos em Passerini (2019b), esta teria sido a primeira vez que se usou uma metáfora geneticista para aludir à origem de nosso idioma.

Na sequência, o filho pergunta qual das línguas destacadas seria a "melhor e mais elegante", ao que o pai responde "A que mais se conforma com a latina, assim em vocábulos como na ortografia" (BARROS, 2007 [1540], p.46). Aqui notamos a primeira representação do ideal clássico de língua: se a melhor língua deve ser criada "à imagem e semelhança" do latim do ponto de vista vocabular e ortográfico, ele é o modelo de excelência. Destacamos, ainda, que tal visão é fruto de uma memória construída ao longo dos séculos com relação à própria língua latina.

Partindo dessa premissa, observamos um duplo movimento de representação: inicialmente a do latim, visto como "o ideal". Posteriormente, o destaque que determinado idioma teria, caso mantivesse os mesmos traços da língua modelar. Diante disso, cria-se, entre os povos de língua românica, uma visão de que a "conformidade" com o idioma de origem era motivo de orgulho, tanto maior fossem as semelhanças. Por conseguinte, a representação da melhor língua coincide com a valorização da sua "latinidade". 
O ideal clássico de língua em diálogos do século XVI:

memória e representação do português

O filho continua o diálogo mencionando o fato de muitos considerarem o castelhano em posição de vantagem ao português. A nosso ver, trata-se de uma menção, embora indireta, ao uso da língua castelhana pelos eruditos portugueses, em detrimento de sua língua materna. Como resposta, o pai adota uma postura aparentemente conciliadora, informando que "há de saber d'ambas tanto que entenda os defeitos e perfeições de cada uma” (BARROS, 2007 [1540], p. 47). No entanto, mais adiante, ele torna a mencionar a "conformidade" com o latim como aspecto preponderante da língua e conclui: "Aí começarás tu de sentir o louvor da nossa linguagem que, sendo nossa, a entenderá o latino porque é sua. Esta prerrogativa tem sobre todas as linguagens presentes: majestade para coisas graves e uma eficácia baroil que representa grandes feitos [...]" (ibid, p. 48).

Como se pode perceber, o pai fala sobre o "louvor" do português e aponta, como razão, a semelhança entre as línguas. Aqui notamos um fenômeno curioso: embora o diálogo seja precipuamente laudatório, esse movimento, de certa forma, acaba por também "defender" o português das acusações que lhe eram perpetradas de ser uma língua "menor" que o castelhano. Por isso, entendemos que, em ambos os diálogos, as ações de defesa e louvor se retroalimentam, pois partem de uma mesma motivação, relacionada tanto ao patriotismo da língua quanto ao seu discurso apologético. Nas palavras de Buescu (1978, pp.45-46),

A posição de João de Barros no que respeita a este ponto [o louvor da língua portuguesa], parece que se insere na polémica mais ou menos latente durante os séculos XVI e XVII entre os decididos apologistas da língua nacional e os que reconheciam a superioridade da castelhana como língua de maior circulação, expressividade e riqueza. Contra esses, opõe-se vigorosamente João de Barros, atribuindo à língua portuguesa, como qualidades essenciais, riqueza vocabular, conformidade com o latim, gravidade e majestade, sonoridade agradável, capacidade de exprimir ideias abstractas, possibilidade de formação de novos vocábulos.

Em continuidade, o pai destaca a copiosidade vocabular, enfatizando que "A linguagem portuguesa [...] não perde força para declarar, mover, deleitar e exortar a parte a que se inclina, seja em qualquer gênero de escritura" (BARROS, 2007 [1540], p. 49). Mais uma vez, a memória greco-latina é evocada, sobretudo porque os exemplos dados pelo pai fazem alusão a personagens da Antiguidade Clássica, como se nota no seguinte trecho:

Certo, a quem não falecer matéria e engenho para demonstrar sua tenção, em nossa linguagem não lhe falecerão vocábulos. Porque é de crer que, se Aristóteles fora nosso natural, não fora buscar linguagem 
emprestada para escrever na filosofia e em todas as outras matérias de que tratou" (BARROS, 2007 [1540], p.49).

Dessa fala, depreendemos que o ideal clássico de língua agora é associado à abundância vocabular e, na fala de Barros, o português, o grego e o latim são representados em condições de igualdade.

O filho faz um novo questionamento, agora com relação à criação de novas palavras. Mais especificamente, ele pergunta se, na falta de determinado vocábulo, o português "poderia formar algum verbo aprazível à orelha, sem falar por rodeio como essoutros [os franceses, os italianos e os castelhanos] fazem" (ibid, p.50). A resposta é afirmativa, “[...] porque a licença que Horácio em sua arte poética [...] dá aos latinos para comporem vocábulos novos, contanto que saiam da fonte grega, essa podemos tomar, se os derivarmos da latina" (ibid, p.50).

Nesse trecho, novamente é visível o ideal clássico de língua, que tem no latim a fonte legítima da qual devem beber os autores em suas composições. No entanto, ressaltamos, aqui, outro aspecto da memória e da representação. Ao citar Horácio, o pai comenta que o pensador romano preconizava a preferência por fontes gregas para a criação de palavras. Assim, o grego era representado como ideal de língua e estava, a seu tempo, na memória dos falantes do latim. Isso mostra uma continuidade do pensamento linguístico entre os falantes do latim e os do português, pois ambos mantêm a mesma postura de tomada de modelos de correção e perfeição. Nosso parecer é comprovado por outro trecho do diálogo, em que o pai considera:

Quero dizer que Túlio, César, Lívio e todos os outros a que chamamos fonte da eloquência nunca aprenderam língua latina como a grega, porque era sua natural linguagem, tão comum ao povo romano, como vemos que a nossa é ao povo de Lisboa, mas souberam a gramática dela. Esta lhes ensinou que coisa era nome, e quantas qualidades e figuras tinha [...]. Destas coisas foram os latinos tão curiosos, por apurar sua língua, e à igualarem à grega (donde eles tomaram parte de sua eloquência) que se escreve compoer César um tratado de analogia da língua latina, e Messala a cada letra do a, b, c fez um livro que trata delas, e Varrão outro da Ethimologia, de que ao presente temos alguma parte (BARROS, 2007 [1540], p.52).

Em outro momento, o filho pergunta se todos os conhecedores do latim poderiam criar novas palavras. $\mathrm{O}$ pai responde negativamente e adverte que a criação deve acontecer desde que "a natureza da nossa linguagem aceite". Além disso, diz que os portugueses devem prezar pelos termos já presentes na 
O ideal clássico de língua em diálogos do século XVI:

memória e representação do português

língua e não apenas "os que achamos por escrituras antigas, mas muitos que se usam entre Douro e Minho, conservador da semente portuguesa, os quais alguns indoutos desprezam por não saberem a raiz donde nascem" (ibid, p.51).

Nesse trecho, o pai curiosamente cita os usos presentes na região do EntreDouro-e- Minho e a considera como o "conservador da semente portuguesa". Sabemos que, por tradição, a história considera essa região o "berço" de Portugal. Além disso, o galego teria surgido nesse mesmo espaço, e aqui notamos um possível apagamento dessa língua na origem do idioma lusitano. Sobre as razões que teriam motivado tal postura, sugerimos a leitura de Bagno (2012) e Passerini (2019b).

O último motivo de "louvor" que destacamos é o fato de o português estar associado ao expansionismo linguístico, o que lhe confere a "majestade" citada por Buescu (1978). Essa característica torna-se mais evidente no fim do diálogo, quando o pai faz a seguinte reflexão:

E o mais certo sinal que o romano pode dar ser Espanha súdita ao seu império, não serão suas crônicas e escrituras, cá estas, muitas vezes são favoráveis ao senhor de quem falam, mas a sua linguagem, que nos ficou em testemunho de sua vitória. E quanto, entre as coisas materiais, é de maior excelência aquela que mais dura, tanto acerca das coisas da honra, são de maior glória as que a memória mais retém. Exemplo temos em todas as monarquias, cá, se perderam com a variedade do tempo e fortuna das coisas humanas, pero deixou a língua latina este sinal de seu império, que durará eternamente. As armas e padrões portugueses postos em África e Ásia, e em tantas mil ilhas fora da repartição das três partes da terra, materiais são, e pode-as o tempo gastar, pero não gastará doutrina, costumes, linguagem, que os portugueses nestas terras deixarem (BARROS, 2007 [1540], p. 53).

O próprio Barros menciona a relação da língua com a memória, mencionando o papel de ambas na perpetuação dos feitos gloriosos de determinado povo. Nesse caso, o português seria imortalizado, tal qual o latim, cuja memória é exaltada ao longo de todo o diálogo e cuja representação é a de uma língua modelar, à qual o português se assemelha. Da mesma forma, apresenta-se a língua portuguesa como herdeira da latinidade e, por conta disso, digna do mesmo destaque de seu nobre antecessor. Assim, o ideal de língua clássica, nesse momento, é o ideal de língua imperial, levada aos povos subjugados a fim de garantir o domínio do colonizador. Essa associação é essencial à construção da memória do português que, assim como o idioma latino, deve ser visto como a língua de um grande império. 
O diálogo de Gândavo segue um percurso semelhante, embora trate precipuamente da "defesa" do idioma, por razões já mencionadas. O embate se dá entre Petrônio, o português, e Falêncio, o castelhano, cujas respostas são geralmente refutadas pela personagem portuguesa. A cena tem início com a fala do português, no intento de provar que a língua portuguesa é "em si tão grave e tão excelente assim na prosa como no verso que só a latina lhe pode nesta parte fazer vantagem" (GÂNDAVO, 2007 [1574], p.67). Já nesse momento, é nítido que Gândavo parte do mesmo ideal de língua que Barros, ao associar o latim a um modelo de perfeição. Desse modo, o português é representado como uma língua superior às demais da mesma família e que perde, em grandiosidade, apenas para o idioma latino.

A resposta de Falêncio é a de que a língua portuguesa era julgada "não só por todas as nações do mundo, mas ainda pelos próprios portugueses que a possuem "' (ibid, p. 68) pelo fato de ter sido, em seu princípio, um idioma no qual se "usavam muitos vocábulos muito diferentes e impróprios de seu natural

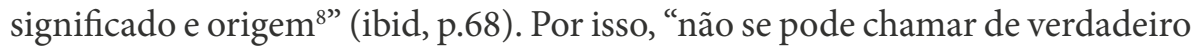
Português o destes tempos usuais, mas o antigo que em princípio se usava, como eu já disse ${ }^{9}$ (ibid., p.68)". Da fala do espanhol, enfatizamos a menção aos próprios lusos que criticam seu idioma, uma referência ao fato de ele não ser, à época, o preferido dos eruditos do reino, que ainda optavam por escrever em castelhano ou em até mesmo em latim.

Na sequência, Petrônio justifica que essa língua inicial a que se refere Falêncio como "tosca e rude" era nada mais que um "latim vulgar", afinal, o português, apesar de ser uma língua "inventada como foram as outras", tinha um componente incontestavelmente latino, do qual "todos estes nossos vocábulos, ou a maior parte deles, trazem sua origem" (ibid, p.69). Assim, fica evidente, também no diálogo de Gândavo, a necessidade de reafirmação da origem latina do português e, para tanto, promove-se, outra vez, um apagamento do galego, aqui substituído pelo termo genérico "latim vulgar". Esse aspecto é essencial para a construção da memória do idioma, em franco processo de institucionalização no século XVI, como já dissemos.

7 Tradução nossa, do espanhol: "no sólo de todas las naciones del mundo, mas aún de los mismos Portugueses que la poseen".

8 Tradução nossa, do espanhol: "usaban muchos vocablos muy diferentes y improprios de su natural significacion y origen"

9 Tradução nossa, do espanhol: "no puede llamar verdadero Portugués el que ahora en estos tiempos usuais, sino el antiguo que en principio se usava, como ya tengo dicho". 
O ideal clássico de língua em diálogos do século XVI:

Mais adiante, a personagem lusitana complementa sua fala dizendo que a língua teria se modificado ou, em suas palavras, "apurado-se", dadas as novas realidades com as quais se foi deparando ao longo do tempo. Apesar do acréscimo de vocábulos não pertencentes ao latim, eles são adequados àquilo que se pretende exprimir e "soam melhor aos ouvidos de gente polida" (ibid., p.69). No entanto, Petrônio faz a seguinte advertência:

Ora naqueles em que seguimos o latim não há que repreender, pois claramente se vê que quanto mais a ele nos chegamos, tanto melhor parecem e mais autorizada fica a nossa linguagem. Pela qual razão se não pode negar ser este o natural e verdadeiro português que agora usamos: no qual se desapaixonadamente quiserdes por os olhos, e notar a etimologia e significação de alguns vocábulos desta nossa língua achareis que em muitas partes faz vantagem à vossa[...] e é que dizemos olhar e vós mirar [...]. E, além disso, outros termos cá que vós lá careceis [...] convém a saber, dizemos jeito, saudade, lembrança, praguejar, enxergar, agasalhar, etc. (ibid, p. 69-70).

Das palavras da personagem, destacamos, a princípio, o fato de ela afirmar que, quanto maior proximidade houver entre o português e o latim, mais a sua língua se tornará "autorizada". Ou seja, a semelhança com o latim continua sendo um ideal, embora haja uma consciência de independência entre as ambas. Segundo Buescu (1978, p. 15), não se trata "[...] de tentar reviver e admirar passiva e acriticamente o passado clássico. Trata-se, principalmente, de revestir esse legado duma arte nova". Nesse ponto, é nítido que o interlocutor português afirma que a antiga língua falada era um latim vulgar e que a atual seria efetivamente o português. Ainda assim, há muita semelhança entre ambas, e isso continua a ser motivo de louvor, e não de vergonha, pois mostra a sua relação "genética".

Em outro momento, Falêncio retoma a posição de ataque e utiliza novamente o argumento de o castelhano ser uma língua corrente em Portugal. Em suas palavras "Porque homens portugueses muito importantes e de grandes engenhos escreveram, e ainda hoje escrevem, suas obras em castelhano por ser linguagem mais apreciável e doce, e soar melhor aos ouvidos que a vossa ${ }^{10 "}$ (GÂNDAVO, 2007 [1574], p.73). Levando em conta a função do diálogo, o reforço dessa característica demonstra a relevância do discurso apologético construído ao

10 Tradução nossa, do espanhol: "Porque hombres portugueses muy principales y de grandes ingenios escribieron, y aún hoy en dia escriben, sus obras en castellano por ser el lenguaje más apreciable y dulce, y sonar mejor a los oídos que la vuestra" 
"defender" o português da língua do reino vizinho que, àquela altura, era um perigo mais que iminente à soberania do povo lusitano.

A resposta de Petrônio não desmente a constatação do seu interlocutor, mas acrescenta que os autores lusitanos que se valeram da língua de Falêncio o fizeram "por seu passatempo e églogas, canções, elegias e cantos pastoris, que são matérias leves e acomodadas ao estilo da mesma língua" (ibid., p.73). Assim, para os gêneros de menos "gravidade" não era de se espantar que fosse usado o castelhano.

Entretanto, em textos de mais erudição ou, nas palavras do próprio Petrônio, em "coisas mais graves e de importância", ele nega que os autores tanto antigos quanto modernos tenham se valido do outro idioma. Na sequência, cita-se uma série de autores cujas obras foram escritas em português, dentre eles João de Barros, Luís de Camões e Diogo Bernardes. Em seguida, a personagem portuguesa propõe a Falêncio a leitura da gramática de João de Barros, a fim de comprovar a semelhança entre o português e o latim, ou então do Livro da Antiguidade de Évora, de André de Resende, "onde claramente se mostra, que com pouca corrupção deixa de ser Latina” (ibid., p.74).

Diante desse argumento, o interlocutor castelhano faz um pequeno inventário de palavras que, em seu idioma, se assemelham muito ao latim, tais como colores, dolores, passiones, entre outras. Em resposta, Petrônio cita outras tantas que, em português, são mais próximas da latina, por exemplo, femia, ferro, fazer etc. Adiante, ele apresenta um poema que teria sido feito em uma disputa em Paris, na qual os participantes deveriam compor versos utilizando apenas palavras de origem latina. Segundo Petrônio, a língua portuguesa teria sido a vitoriosa, por apresentar o maior número de vocábulos mais próximos do idioma latino. Curiosamente, os versos citados são os mesmos utilizados por Barros no seu Diálogo. Isso comprova, em grande medida, a influência desse autor sobre o texto de Gândavo, que certamente teria se inspirado na obra de seu coetâneo para escrever uma "defesa" do português.

Embora menos elaborado que o de João de Barros, o diálogo de Pero Magalhães de Gândavo apresenta o mesmo ideal clássico de língua, como reflexo tanto do clima de opinião renascentista quanto do momento em que fora produzido, no qual a "defesa" do idioma lusitano era ainda mais necessária. Desse modo, apesar de se circunscrever em um momento histórico um pouco distinto de seu antecessor, é possível observar uma continuidade no propósito de representação do português como uma língua indiscutivelmente latina, cuja relação de semelhança com o idioma de origem é notória e a torna superior às demais línguas da "família" românica. 
O ideal clássico de língua em diálogos do século XVI:

memória e representação do português

\section{Considerações finais}

No início de nosso capítulo, ocupamo-nos de definir a memória e mostrar como ela se associa ao conceito de representação postulado por Chartier (1991 [1989]). Na discussão promovida a respeito dos dois conceitos, percebemos a convergência de ambos na formação da identidade de um povo entre seus semelhantes e perante a outros povos. Diante disso, propusemo-nos à análise daquilo que consideramos o ideal clássico de língua, com base nos dois diálogos linguísticos publicados no século XVI em Portugal. Para tanto, baseamo-nos nos preceitos metodológicos concernentes à História das Ideias Linguísticas, sobretudo os postulados por Auroux (2014 [1992]).

Considerando o princípio do historicismo moderado (AUROUX, 2014 [1992]), reconstruímos o clima de opinião e constatamos a sua relação com o início do processo de gramatização da língua portuguesa, que coincide com o apogeu e a derrocada de um dos maiores impérios da Idade Moderna. Nesse sentido, uma série de fatores motivou o surgimento da gramática em solo lusitano, em resposta às necessidades com que se depararam os portugueses, por conta das grandes navegações.

O clima intelectual da época era permeado pelos ideais renascentistas, e o Classicismo propiciou um retorno ao passado greco-latino, tido como inspiração para artistas e demais intelectuais. No processo de instrumentalização do português, verificou-se grande pendor patriótico no trato com a língua, representada nos textos selecionados como herdeira legítima do latim, com o qual mantinha relações de similitude que lhe conferiam ainda mais destaque entre as demais línguas românicas.

Assim, baseados nos ideais do Renascimento, os primeiros estudiosos do idioma valeram-se de um discurso fundador que procurava dar uma origem nobre ao português e encontraram no latim o "berço" de uma língua igualmente nobre e imperial. Nessa empreitada, criou-se uma memória do idioma, a fim de que ele fosse representado dentro e fora de Portugal por todas as virtudes que lhe eram inerentes. Concomitantemente, os autores se valeram de uma memória já existente acerca do latim, representado nos textos como o verdadeiro modelo a ser seguido.

Considerando os diferentes momentos em que se produziram os diálogos, igualmente pudemos perceber a razão de um se dedicar ao louvor, e o outro, à defesa. No primeiro momento, o império acabara de atingir o ápice das conquistas ultramarinas; no segundo, já dava sinais da iminente crise, consolidada seis anos após a publicação do texto de Gândavo, quando o reino lusitano é anexado ao de seu mais temido vizinho. Nesse sentido, destacamos também que, do ponto de vista linguístico, o castelhano já era "ameaça" constante, devido 
ao seu uso como língua de erudição em Portugal, o que também motivou a escrita de textos claramente apologéticos ao português. Afirmamos isso pelo fato de nossa análise ter demonstrado que, em ambos os textos, louvor e defesa se articulam e se tornam interdependentes.

Partindo da premissa da descrição fenomenológica do objeto e da neutralidade epistemológica (AUROUX, 2014 [1992]), detectamos que, no texto de Barros, a proposta de louvor ao português é baseada no elemento latino, responsável pela elegância do idioma e por seu tom majestoso. O diálogo de Gândavo, da mesma maneira, acaba por tecer uma série de louvores ao português, embora se proponha precipuamente a defendê-lo. Nele, a menção ao "inimigo" castelhano é muito mais clara, o que nos leva à constatação de que, naquela altura, o seu uso no território português era um problema a ser resolvido com urgência.

Assim os pioneiros no estudo de nossa língua se empenharam em construir a imagem dela perante aos portugueses e também aos outros povos: por meio do enaltecimento de suas virtudes, inextricavelmente ligadas ao latim, representado como língua modelar, ideal, o progenitor de quem o português herdara as semelhanças e, por conta delas, a nobreza. Nesse movimento, buscou-se eternizar não só a origem do idioma lusitano, como também perpetuar, ao longo dos séculos, os grandes feitos do seu povo, graças à força da representação e ao poder atemporal da Memória.

\section{Referências}

\section{Fontes primárias}

BARROS, João de. Gramática da lingua portuguesa. Lisboa: Olyssipone, 1540.

BARROS, João de; GÂNDAVO, Pero de Magalhães de. Diálogos em defesa e em louvor da língua portuguesa. Edição, introdução e notas de Sheila Moura Hue. Rio de Janeiro: 7 Letras, 2007.

GÂNDAVO, Pero de Magalhães de. Regras que ensinam a maneira de escrever e ortographia da lingua portuguesa, com hum Dialogo que a diante se segue em defensam da mesma lingua. Lisboa: Antonio Gonsalvez, 1574.

\section{Fontes secundárias}

ADAMI, Ana Letícia. O gênero dialógico no Renascimento e o diálogo Sobre o Prazer de Lorenzo Valla. In.: Anais do XXIX Simpósio Nacional de História-contra os preconceitos: história e democracia. Brasília: UnB, 2017. Disponível em: https://www.snh2017. anpuh.org/site/anais. Acesso em: 30/01/2020.

AUROUX, Sylvain. A revolução tecnológica da gramatização. 3.ed. Trad. Eni Puccinelli Orlandi. Campinas: Editora Unicamp, 2014 [1992]. 
O ideal clássico de língua em diálogos do século XVI:

memória e representação do português

BAGNO, Marcos. Gramática pedagógica do português brasileiro. São Paulo: Parábola, 2012.

BRANDÃO, Junito de Souza. Mitologia Grega. 26.ed. São Paulo: Editora Vozes, 2015 [1986].

BUESCU, Maria Leonor Carvalhão. Gramáticos portugueses do século XVI. Amadora: Instituto de Cultura Portuguesa, 1978.

BUESCU, Maria Leonor Carvalhão. João de Barros: textos pedagógicos e gramaticais. Lisboa: Editorial Verbo, 1969.

BURKE, Peter. O Renascimento italiano: cultura e sociedade na Itália. Trad.: José Rubens Siqueira. São Paulo: Nova Alexandria, 2010 [1999].

CAMARA JR, Joaquim Mattoso. História da Linguística. 6.ed. São Paulo: Vozes, s/d [1975].

CAMÕES, Luís Vaz de. Os lusíadas. São Paulo: Abril, 2010 [1572].

CHARTIER, Roger. O mundo como representação. Trad. Andréa Daher e Zenir Campos Reis. Estudos avançados, 11 (5), 1991 [1989].

COLOMBAT, Bernard; FOURNIER, Jean-Marie; PUECH, Christian. Uma história das ideias linguísticas. Trad. Jacqueline Léon e Marli Quadros Leite. São Paulo: Contexto, 2017 [2010].

D'ONOFRIO, Salvatore. Literatura ocidental: autores e obras fundamentais. 2.ed. São Paulo: Ática, 2007.

FARACO, Carlos Alberto. História do português. São Paulo: Parábola, 2019.

FARACO, Carlos Alberto. História sociopolitica da Língua Portuguesa. São Paulo: Parábola, 2016.

GARCIA, José Manuel. História de Portugal: uma visão global .2. ed. Lisboa: Presença, 1984.

HESÍODO. Os trabalhos e os dias, Teogonia e O escudo de Héracles. Introdução, tradução para o grego moderno e comentários de Stavros Guirguenis. Thessaloniki: Zitros, 2001. HESÍODO. Teogonia: a origem dos deuses. 3.ed. Estudo e tradução de Jaa Torrano. São Paulo: Iluminuras, 1995.

HUE, Sheila Moura. Introdução. In BARROS, João de; GÂNDAVO, Pero de Magalhães de. Diálogos em defesa e louvor da Língua Portuguesa. Edição, introdução e notas de Sheila Moura Hue. Rio de Janeiro: 7 Letras, 2007.

KONDER, Leandro. O que é dialética? São Paulo: Brasiliense, 2007 [1981].

LE GOFF, Jacques. História e memória. Trad.: Bernardo Leitão, Irene Ferreira e Suzana Borges. 7.ed. Campinas: Editora Unicamp, 2016 [1990].

MARQUES, António Henrique Rodrigo de Oliveira. Breve história de Portugal. 5.ed. Lisboa: Editorial Presença, 2003.

MARQUES, António Henrique Rodrigo de Oliveira. Brevíssima história de Portugal. Rio de Janeiro: Tinta-da-China, 2018 [2016].

MOISÉS, Massaud. A literatura portuguesa. São Paulo: Cultrix, 1999 [1960].

MONTEAGUDO, Henrique. História social da língua galega. Vigo: Galaxia, 1999. 
PASSERINI, Thiago Zilio. Em defesa e em louvor da língua portuguesa: uma análise historiográfica do diálogo de Pero Magalhães de Gândavo. Verbum. v. 8, n. 1, p. 74-91, abr. 2019a

PASSERINI, Thiago Zilio. Ocultação de paternidade ou filiação ilegítima? O lugar do galego na origem da língua portuguesa em textos dos séculos XVI e XIX. Dissertação de Mestrado. Programa de estudos pós-graduados em Língua Portuguesa, Pontifícia Universidade Católica de São Paulo/PUC-SP, São Paulo, 2019b.

PUGLIESI, Márcio. Mitologia greco-romana: arquétipos dos deuses e heróis. 2.ed. São Paulo: Madras, 2005.

RICOEUR, Paul. A memória, a história, o esquecimento. Trad.: Alain François [et al.]. Campinas: Editora da Unicamp, 2018 [2007].

ROSSETTI, Lívio. O diálogo socrático. Trad. Janaína Mafra. 1.ed. São Paulo: Paulus, 2015 [2011].

SANTOS, José Trindade. Para ler Platão: a ontoepistemologia dos diálogos socráticos. Tomo I. 2.ed. São Paulo: Loyola, 2012 [2008].

SCOTT, Ana Silvia. Os portugueses.1. ed. São Paulo: Contexto, 2018.

SICHEL, Edith. O Renascimento. Trad.: Iracilda M. Damasceno. Rio de Janeiro: Zahar Editores, 1963 [1957].

SPINA, Segismundo. Segunda metade do século XVI e Século XVII. In SPINA, Segismundo (org.). História da Língua Portuguesa. Cotia: Ateliê Editorial, 2011 [2008].

TORRANO, Jaa. Ouvir Ver Viver a Canção. In HESÍODO. Teogonia: a origem dos deuses. 3.ed. Estudo e tradução de Jaa Torrano. São Paulo: Iluminuras, 1995.

WEEDWOOD, Barbara. História concisa da Linguística. 5.ed. Trad. Marcos Bagno. São Paulo: Parábola, 2002 [2006]. 